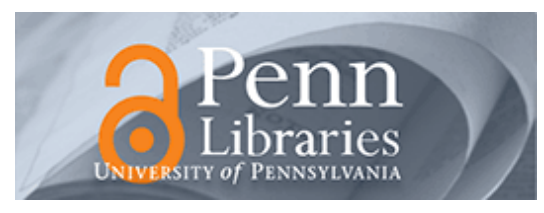

Manuscript Studies

\title{
Replication and Innovation in the Folk Narratives of Telangana: Scroll Paintings of the Padmasali Purana, 1625-2000
}

Anais Da Fonseca

School of Oriental and African Studies

Follow this and additional works at: https://repository.upenn.edu/mss_sims

Part of the Asian Art and Architecture Commons, Asian History Commons, and the South and Southeast Asian Languages and Societies Commons

\section{Recommended Citation}

Da Fonseca, Anais (2019) "Replication and Innovation in the Folk Narratives of Telangana: Scroll Paintings of the Padmasali Purana, 1625-2000," Manuscript Studies: Vol. 4 : Iss. 1 , Article 6.

Available at: https://repository.upenn.edu/mss_sims/vol4/iss1/6 


\title{
Replication and Innovation in the Folk Narratives of Telangana: Scroll Paintings of the Padmasali Purana, 1625-2000
}

\begin{abstract}
In the Southern Indian state of Telangana, itinerant storytellers narrate genealogies of the local castes using a scroll painting on cloth as a visual aid to their performance. These scrolls are the only archive of these otherwise oral narratives; hence key markers of their evolution. Once a scroll commission has been decided, performers bring an old scroll to the painters and request for a 'copy.' Considered as such by both performers and painters, a closer look at several scrolls of the same narrative highlights a certain degree of alteration. This paper focuses on the Padmasali Purana that narrate the origin of the weavers' caste of Telangana. On the basis of five painted scrolls of this same narrative, ranging from 1625 to 2000 , this article explores the nature and degree of modification undergone by the narrative. In so doing, it questions the extant of the concept of replication within the narrative and painting traditions. While performers decide for changes in the overall organisation and iconography of the narrative, painters are responsible for the materiality, technique and style of the scroll. In illustrating each of these aspects, this article argues that changes reflect the social and cultural environment of the communities involved in the production, presentation and reception of these scrolls, i.e. painters, performers and patrons, and that variations but also fixity to be speaking for the necessities of the communities. Finally, it argues that through reproductions over the course of time, aspects of the visual narrative have become conventions while others are repeatedly revised.
\end{abstract}

\section{Keywords}

Manuscript studies, India, Painted scrolls, Caste puranas, Genealogies, Replication 
Da Fonseca: Replication and Innovation in the Folk Narratives of Telangana

\section{MANUSCRIPT STUDIES}

A Journal of the Schoenberg Institute for Manuscript Studies

VOLUME 4, N UMBER 1

(Spring 2019)

Manuscript Studies (ISSN 2381-5329) is published semiannually

by the University of Pennsylvania Press

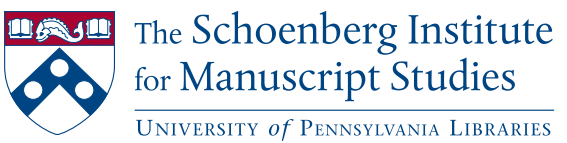




\section{MANUSCRIPT STUDIES}

VOLUME 4 , N UMBER 1

(Spring 2019)

ISSN 2381-5329

Copyright (C 2019 University of Pennsylvania Libraries

and University of Pennsylvania Press. All rights reserved.

Published by the University of Pennsylvania Press, 3905 Spruce Street, Philadelphia, PA 19104.

Printed in the U.S.A. on acid-free paper.

Manuscript Studies brings together scholarship from around the world and across disciplines related to the study of premodern manuscript books and documents, with a special emphasis on the role of digital technologies in advancing manuscript research. Articles for submission should be prepared according to the Chicago Manual of Style, $16^{\text {th }}$ edition, and follow the style guidelines found at http://mss.pennpress.org.

None of the contents of this journal may be reproduced without prior written consent of the University of Pennsylvania Press. Authorization to photocopy is granted by the University of Pennsylvania Press for libraries or other users registered with Copyright Clearance Center (CCC) Transaction Reporting Service, provided that all required fees are verified with CCC and paid directly to CCC, 222 Rosewood Drive, Danvers, MA 01923. This consent does not extend to other kinds of copying for general distribution, for advertising or promotional purposes, for creating new collective works, for database retrieval, or for resale.

\section{SUBSCRIPTION INFORMATION:}

Single issues: $\$ 30$

Print and online subscriptions: Individuals: $\$ 40$; Institutions: $\$ 92$; Full-time Students: $\$ 30$ International subscribers, please add $\$ 18$ per year for shipping.

Online-only subscriptions: Individuals: $\$ 32$; Institutions: $\$ 80$

Please direct all subscription orders, inquiries, requests for single issues, address changes, and other business communications to Penn Press Journals, 3905 Spruce Street, Philadelphia, PA 19104. Phone: 215-573-1295. Fax: 215-746-3636. Email: journals@pobox.upenn.edu. Prepayment is required. Orders may be charged to MasterCard, Visa, and American Express credit cards. Checks and money orders should be made payable to "University of Pennsylvania Press" and sent to the address printed directly above.

One-year subscriptions are valid January 1 through December 31. Subscriptions received after October 31 in any year become effective the following January 1. Subscribers joining midyear receive immediately copies of all issues of Manuscript Studies already in print for that year.

Postmaster: send address changes to Penn Press Journals, 3905 Spruce Street, Philadelphia, PA 19104.

Visit Manuscript Studies on the web at mss.pennpress.org. 


\section{MANUSCRIPT STUDIES}

\section{A Journal of the Schoenberg Institute for Manuscript Studies}

VOLUME 4, N UMBER 1

\section{Articles}

In the Age of Non-Mechanical Reproduction:

Manuscript Variation in Early-Modern South Asia

Arthur Dudney, Neeraja Poddar

Manuscript Variations of Dabistān-i Maz̄āhib

and Writing Histories of Religion in Mughal India

Sudev Sheth

Power Permutations in Early Hindi Manuscripts:

Who Asks the Questions and Who Gives the Answers,

Rāmānand or Kabīr?

Heide Paunels

The Strange Afterlife of Vidyāpati Thākura (ca. 1350-1450

$\mathrm{CE}$ ): Anthological Manuscripts, Linguistic Confusion, and Religious Appropriation

CHRistopher L. DiAmond

Prefatory Notes on Persian Idioms of Islamic Jurisprudence:

Reasoning and Procedures of Law-Making in Premodern

Islamicate India

Naveen Kanalu

Replication and Innovation in the Folk Narratives

of Telangana: Scroll Paintings of the Padmasali

Purana, 1625-2000

Anais Da Fonseca

Nectar or Arrow: Cases of Missense Textual Mutations in Early Kabïrian Padas

Zhang Minyu 
Manuscript Studies, Vol. 4 [2019], Iss. 1, Art. 6

iv | Journal for Manuscript Studies

"Publishing" and Publics in a World Without Print:

Vernacular Manuscripts in Early Modern India

Tyler Williams

\section{Reviews}

Kay Davenport. The Bar Books: Manuscripts Illuminated for Renaud de Bar, Bishop of Metz (1303-1316).

RICHARD A. LESON

Matti Peikola, Aleksi Mäkilähde, Hanna Salmi, Mari-Liisa

Varila, and Janne Skaffari, eds. Verbal and Visual

Communication in Early English Texts.

Lydia Yaitsky Kertz

Alpo Honkapohja. Alchemy, Medicine, and Commercial

Book Production: A Codicological and Linguistic Study

of the Voigts-Sloane Manuscript Group.

Winston BLACK

List of Manuscripts Cited 


\title{
Replication and Innovation in the Folk Narratives of Telangana: Scroll Paintings of the Padmasali Purana, 1625-2000
}

\author{
Anais Da Fonseca \\ School of Oriental and African Studies
}

I

N THE SOUTHERN INDiAn region of Telangana, itinerant storytellers narrate genealogies of the local low castes using a hand-painted scroll on cloth as a visual aid to their performance. These scrolls are made of a thick canvas cloth, measure around ten meters, and are presented to a village audience including the patron who commissioned the performance. Because these performances are slowly declining and have not been systematically recorded, the scroll is a valuable source of information, the only archive and tangible means to reconstitute the otherwise oral narratives of these communities; hence, they are key markers of their evolution. ${ }^{1}$

1 Scroll painting for performances in Telangana was first brought to light in 1963 with a publication by S. Welch, R. Ettinghausen, and J. Mittal, "Portfolio," Marg, A Magazine of the Arts 16 (1963): 7-22. Jagdish Mittal, "The Painted Scrolls of the Deccani Picture Showmen: Seventeenth to Nineteenth Century," in Picture Showmen: Insights into the Narrative Tradition in Indian Art, ed. Jyotindra Jain (Mumbai: Marg Publications on behalf of National Centre for the Performing Arts, 1998), 56-65; Jagdish Mittal, Deccani Scroll Paintings in the Jagdish and Kamla Mittal Museum of Indian Art (Hyderabad: Jagdish and Kamla Mittal Museum of Indian Art, 2014); and Kirtana Thanhgavelu, "The Painted Puranas of Telangana: A Study of a Scroll Painting Tradition in South India,” Ph.D. diss., University of California, Berkeley, 1998, constitute the bulk of scholarship on the subject. Following the revival initia- 
Manuscript Studies, Vol. 4 [2019], Iss. 1, Art. 6

Once the commission of a new scroll is decided, performers bring an old scroll to the painters and request a "copy."2 Considered as such by both painters and performers, a closer look at several scrolls of the same narrative highlights a certain degree of alteration. This article focuses on the Padmasali Purana that narrates the origin of the weavers' caste of Telangana. On the basis of five painted scrolls illustrating the same story, ranging from 1625 to 2000, this article explores the nature and degree of modification undergone by the visual narrative. In so doing, it examines the concept of replication within this painting tradition. While performers make changes in the overall organization and iconography of the narrative, painters may interfere in the technical creation by altering the choice of canvas and pigments as well as the style of the scroll. In illustrating each of these aspects, I argue that changes reflect the social and cultural environment of the communities involved in the production, presentation, and reception of these scrolls - that is, painters, performers, and patrons - and that potential variations but more particularly fixed elements speak to the needs of these communities. Finally, I further argue that through the reproduction of scrolls over the course of time, certain aspects of the visual narrative have become conventions, while others are repeatedly revised.

\section{The Scroll and Its Painters, Performers, and Patrons}

The subject matter of these scrolls is to present the "history" of the patron caste who commissioned the performance under the form of a Purana. Also known as kula (lineage or family) Puranas, these local castes' genealogies

tives of the All India Handicraft Board in the 1980s, scroll painting for performance has become secondary and more various formats and supports are now painted in the same style for museums and the handicraft market. The continuity and changes in the painting tradition have been the subject of my Ph.D. research between 2012 and 2017 from which this paper is an excerpt.

2 "Copy" in English is the word used by the Nakashi painters while asked about the process of making a new scroll. 


\section{Da Fonseca: Replication and Innovation in the Folk Narratives of Telangana}

\section{Journal For Manuscript Studies}

translate in Telugu as Puranam or Puranamu. ${ }^{3}$ The use of the word Purana to describe these genealogical narratives offers two important indications of their function. The first comes from the meaning of Purana in Sanskrit, "old," and confers to these narratives an ancient origin. The second is the direct association with the literary genre of the Purana, which enjoys a classical and authoritative status within Hindu religious literature. The Puranas deal with five specific themes: creation, re-creation, genealogies, Manu-cycles of time, and the histories of dynasties. ${ }^{4}$ They are divided into eighteen Maha-Puranas dealing with the themes mentioned above and eighteen Upa-Puranas, to local gods and cults. ${ }^{5}$ Apart from those, there are several other texts that claim to be Puranas, among them the caste Puranas. ${ }^{6}$ Considered as alternative "folk Puranas," the kulapuranas narrate the genealogies of a particular caste and its divine origin. ${ }^{7}$ The name of the story is known on the basis of the name of the patron caste or that of the main deity or hero of that particular narrative. For instance, the Jambavanta Purana is named after the hero Jambavanta, founder of the Madiga caste for which the story is performed. The Katam Raju Katha is named after Katam Raju, the founder of the Golla caste, but is also known as the Gangamma Purana, after the goddess Gangamma, protector of the community and major figure of the Katam Raju Katha. These narratives also borrow from other Puranas, such as the Kunapuli performing parts of the Markandeya Purana for the Padmasali. Finally, others may narrate portions of the Mababbarata and Ramayana epics.

Organized into professional guilds, these communities belong to the lower strata of the caste system and qualify as OBC (Other Backward Classes)

3 Peter J. Claus, Sarah Diamond, and Margaret Ann Mills, South Asian Folklore: An Encyclopedia: Afghanistan, Bangladesh, India, Nepal, Pakistan, Sri Lanka (New York: Routledge, 2003), 100.

4 Veena Das, "A Sociological Approach to the Caste Puranas: A Case Study," Sociological Bulletin 17, no. 2 (1968): 141.

5 Das, "A Sociological Approach to the Caste Puranas."

6 Das, "A Sociological Approach to the Caste Puranas."

7 Attipate Krishnaswami Ramanujan, "On Folk Mythologies and Folk Puranas," in Purāna Perennis: Reciprocity and Transformation in Hindu and Jaina Texts, ed. Wendy O'Flaherty and Wendy Doniger (Albany: State University of New York Press, 1993), 101-20. 
or SC (Scheduled Castes). ${ }^{8}$ In these Puranas, the communities find their origins in the major deities of the Saivite and Vaishnavite sects of Hinduism. ${ }^{9}$ The narrative will explain how a major Pan-Indian deity necessitated the activity of this community at some point in time, thereby creating the first ancestor of both the profession and the caste group. The use of the puranic genre and affiliation with a main Hindu deity permits the justification of the caste's occupation, the legitimization of its existence, and the assertion of its present status and its continuity. In this regard, Kiratana Thangavelu mentions that the scroll "stood in the background [of the performance] as a canonical, authenticating document." ${ }^{10}$ Because the genealogy of the entire community is based on these Puranas, and their status can be maintained only by the remembrance of these stories, the scroll also serves as a tangible certificate for its patrons. Finally, it is our only tangible means to understand their myth of origin.

The making of a new scroll follows a strict system of patronage that involves three communities: patrons, performers, and painters. Whether these scrolls are recorded in the scroll registers, performed, or transferred orally, they contribute to asserting - and possibly elevating - the status of these castes by making clear that their lineage goes back to the gods, therefore justifying the position of their caste in the local social hierarchy. The narratives, however, deploy not only the origin myth of the patrons but that of their dependent caste, the storytellers themselves. Storytellers earn their livelihood by seeking alms from their patrons, in visiting them regularly and, at times, in performing the Purana with a scroll. Because performers are strictly assigned to certain patrons in certain villages, when a scroll needs to be made, they visit the painting center nearest to these assigned areas. ${ }^{11}$ With this understanding, the scroll also becomes a secular entity

8 The Indian government, for the purpose of the reservation system, classifies people into four categories: General, OBC (Other Backward Classes), SC (Scheduled Castes), and ST (Scheduled Tribes).

9 Mittal, Deccani Scroll Paintings, 12.

10 Kirtana Thangavelu, "The Painted Puranas of Telangana: A Study of a Scroll Painting Tradition in South India,” Ph.D. diss., University of California, Berkeley, 1998, 127.

11 Mittal, Deccani Scroll Paintings, 15, lists several painting centers in Telangana. When I first visited the region in 2012, only one painting center was left, in a village called Cheriyal. 
that federates three communities and participates in maintaining their relationships with one another as well as their personal position within the local social structure, each performing service and duty for the other.

A new scroll is commissioned when the previous one is no longer usable, has been destroyed, or is damaged, or at times when a new band of performers has formed, mostly hereditarily. A scroll is inherited by the eldest son along with the certificate listing the villages in which he is allowed to perform. ${ }^{12}$ If a scroll needs to be made, the performers will visit the painters and order the making of a new one, which usually takes three to six months depending on the length of the narrative. The performers bring an old scroll to the painter, who will sketch the entire new scroll under the acute eye of the performers, copying the main elements and characters as they were on the older one. The performers follow the process carefully to make sure the visual narrative corresponds to their expectations. The new scroll may be identical to the old one, or some alterations to the visual rendering of the story may be made to facilitate the performance. The sketching process lasts several days, and the performers then leave to come back midway during the production process to ensure that everything looks as they dictated; if they approve, the painters can finalize the painting. If no changes are requested, each episode and each character depicted on the old scroll will be replicated in the new one. Whether or not changes in the narrative have been requested, the new scroll will be considered a "copy." In reality, however, a closer look at several scrolls of the same narrative highlights a certain degree of alteration, originating either in the performers' modification of the visual narrative to adjust to the oral rendering or in the painter's hand.

Records of performances show few similarities between the visual narratives of the scroll and the oral narration of the performers. The scenes are principally depicted to help the storyteller to remember the story and to authenticate the narrative. ${ }^{13}$ Evidently, not all the scenes of the entire Purana

12 Mittal, Deccani Scroll Paintings, 13, and Thangavelu, “The Painted Puranas of Telangana," 91-92, both explain the system of inheritance of the scroll.

13 Thangavelu, "The Painted Puranas of Telangana," 127. 
can be depicted, so the choice of scenes reflects negotiations between the performers' needs and the painters' abilities. Performers tend to have a more decisive word on the narrative, while painters have more say on the style.

Kirtana Thangavelu highlights that for the painters, the most important element in the scroll is the line that circles figures, the "naksh," because it is what distinguishes a good painter from a bad one. ${ }^{14}$ While this difference in the painters' hands may be of interest to the painters themselves and art historians, it means little to the performers or patrons. To them, religiosity and visual accuracy should be foremost, as the scroll is a sacred object that embodies the deity's presence. Upon completion of a new scroll, the master painter performs a consecrating ceremony in which he paints the eyes of the deities before handing the object over to the performers with blessings. Later, during a performance, the audience is invited to worship the deities depicted on the scroll.

In addition, visual accuracy should be understood in relation to the patrons' genealogies and measured by the fixity of the story that reflects on both the major events of the oral narration and those of the scroll. Without the painters' blessings, the scroll would be deemed cursed and unusable, and unwelcomed changes in the narrative would go against the patron's fixed origin myth and risk the performers' work. Therefore, performers and painters play different roles in the visual rendering of the scroll, the former being responsible for the narrative and iconography, and the other responsible for religiosity and style.

Understanding both painters' and performers' responsibilities in the making of a scroll is important, as both are concerned with the functional necessities of the scroll, which are to record the patron's origin myths and legitimize his social status. These necessities further inform our understanding of the concept of replication in this context. While both painters and performers consider a new scroll as a copy of the previous one, they do not consider minor alterations of narrative and style as an antithesis to this copy. So long as the main characters, deities, episodes of filiations, and any

14 Thangavelu, "The Painted Puranas of Telangana," 22. 
other key iconographic or narrative markers follow the conventionalfixed-ancestral depiction as recorded in the previous scrolls, no modification hampers the social function of the scroll, and therefore no modification goes against their definition of a "copy." Replication becomes a flexible notion, attached to the religious and social function of the object that is replicated.

It may be worth recalling the making of murti in India here, the two- or three-dimensional images of Hindu deities found in temples and homes that are used for worship. These are regularly duplicated, at times even mass-printed, but the duplicates carry the same religious potency as the "originals." The consecration of a newly made scroll through the painting of the eye inflates the murti with such potency. Pika Ghosh explored the duplication of one such murti, that of Madan Mohan from Vishnupur. Through a series of partly historical partly mythological events, a devotee of Madan Mohan from Vishnupur would have exchanged the murti for money to a merchant in Calcutta. The merchant then became a devotee of Madan Mohan himself, leading to the duplication of the murti to satisfy the newly formed devotional community in Calcutta. ${ }^{15}$ In this context, Ghosh explains that "a new center defined itself in relation to an older one, and in part gained legitimacy by establishing continuities through the physical presence of the divine image." ${ }^{16}$ She adds that replication in the context of the Madan Mohan by the newly formed Calcutta community discloses "anxieties about authenticity, identity, and locality formation," which is something shared with the replication of Telangana scrolls over time as well. ${ }^{17}$ The duplication of an image that represented a devotional community in Vishnupur served to assert the authority of a new place. The replication of scrolls in Telangana serves as a temporal ubiquity rather than a geographical one. Similarly, the duplicate scrolls carry the authority of the original but, this time, from a past to a present.

15 Pika Ghosh, "Sojourns of a Peripatetic Deity," RES: Anthropology and Aesthetics, 41 (2002): 104-26.

16 Ghosh, "Sojourns of a Peripatetic Deity," 106.

17 Ghosh, "Sojourns of a Peripatetic Deity." 
Manuscript Studies, Vol. 4 [2019], Iss. 1, Art. 6

Da Fonseca, Folk Narratives of Telangana

\section{The Padmasali Purana}

The Padmasali Purana is painted for the performance of the weaver caste. The story recited by the Kunapuli for the Padmasali is that of Bhavana Rishi, the direct founder of the community. The legend of the Padmasali is also associated with that of the sage Markandeya and is often referred to as the Markandeya Purana even if it takes into its narratives only a few elements of it. Although the "Markandeya" or "Bhavana Rishi Purana" is more meaningful to the Padmasali due to its puranic affiliation and the authoritative nature of the literary genre, the name Padmasali Purana is chosen here as it highlights the direct reference to the community for which the story is depicted and narrated. The scrolls of the Padmasali Purana have been the most extensively collected over time, but due to the contemporary decline in patronage, they are now virtually absent from circulation. ${ }^{18}$ The oldest scroll is from 1625 (scroll A) and the most recent from circa 2000 (scroll E).

This article compares five full scrolls of the story. The first three scrolls come from the most comprehensive collection of Telangana scrolls, the Jagdish and Kamla Mittal collection in Hyderabad, scroll A (ca. 1625), scroll B (ca. 1750-80), and scroll D (ca. 1780-1820) (acc. no. respectively 76.469/471/470). In addition, the discussion includes one of the scrolls from the British Museum (scroll C, ca. 1770-1800; acc. no. 0615,0.1; fig. 1) and one more on display at the Indira Gandhi Rashtriya Manav Sangrahalaya (IGRMS) in Bhopal (scroll E, ca. 2000; fig. 2); both are reproduced in full in this article. The scrolls will not be analyzed entirely but only for their main features and for their comparable transcriptions of the narrative.

Without a full record of the performance, it is impossible to know with exactitude every episode of the narrative as depicted on the scroll and as narrated by the storytellers. The episodes on the scroll do not necessarily follow the storytelling but serve as an aide-memoire and as an authenticating document that does not strictly illustrate the oral narrative. The painted

18 P. Sadanandam, Art and Culture of the Marginalised Nomadic Tribes of Andhra Pradesh (New Delhi: Gyan, 2008), 92. 
Da Fonseca: Replication and Innovation in the Folk Narratives of Telangana

120 Journal For Manuscript Studies
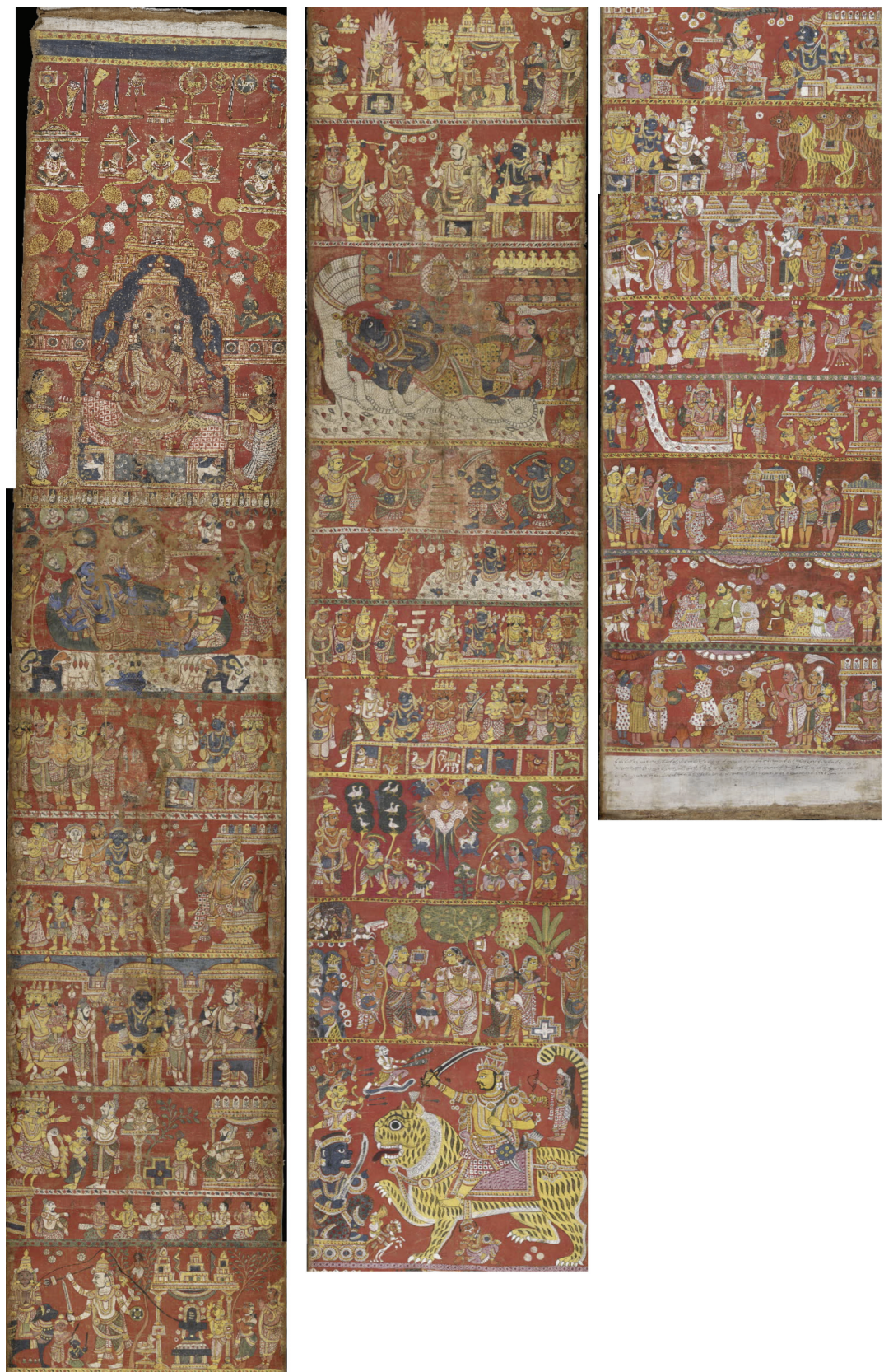

FIGURE 1. Scroll C: Markandeya Purana, ca. $1770-1800,930 \times 85.5 \mathrm{~cm}$, natural paint on cotton cloth, British Museum London, acc. no. 0615,0.1. (C) Trustees of the British Museum. 
Manuscript Studies, Vol. 4 [2019], Iss. 1, Art. 6
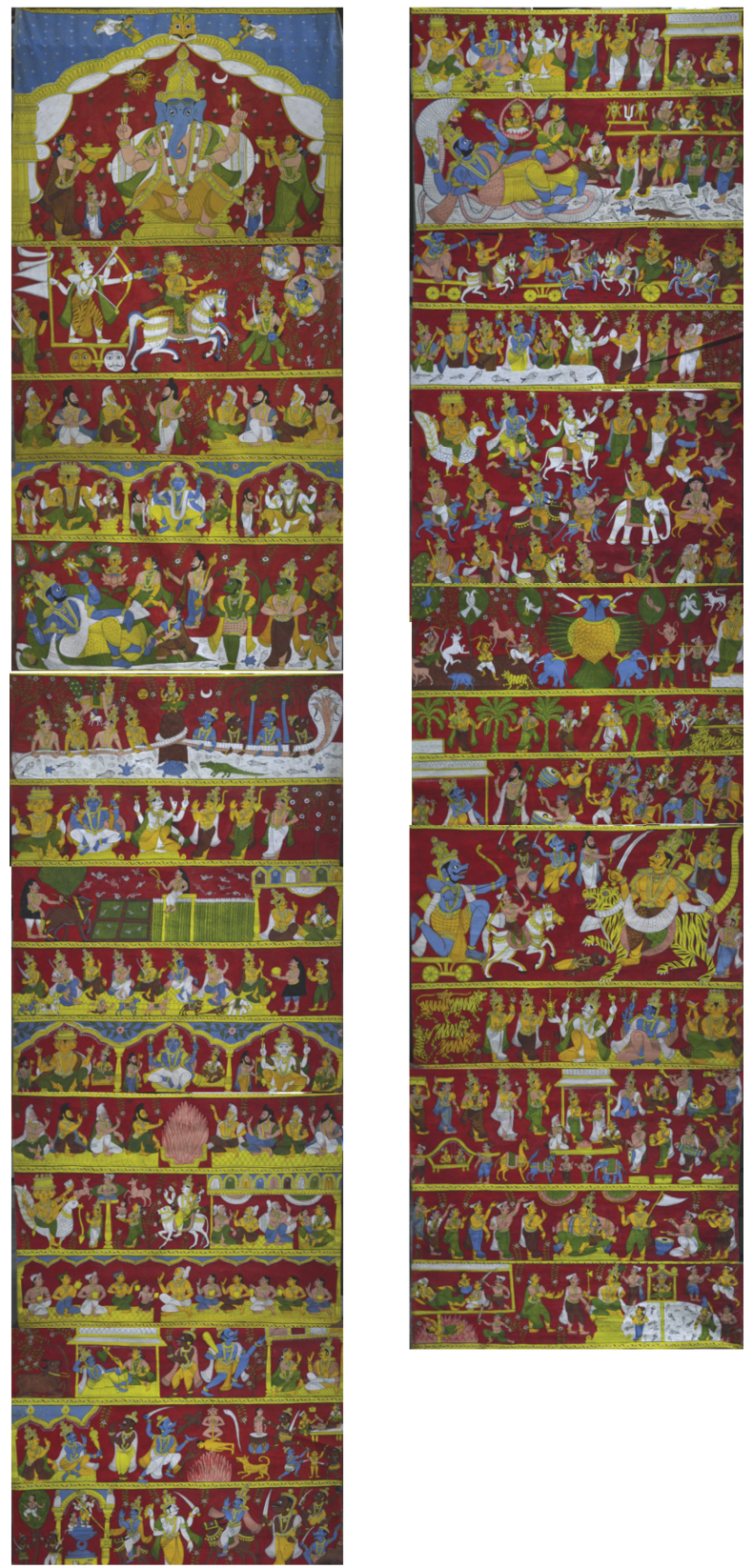

FIguRe 2. Scroll E: Markandeya Purana, ca. 2000, $91.5 \times$ $915 \mathrm{~cm}$, watercolor on canvas, Indira Gandhi Rashtriya Manav Sangrahalaya, Bhopal. Photograph by author. 
narrative is selective of the most important events or those that need a reminder for the performance. Anna Dallapiccola describes two scrolls of the Padmasali Purana (as the Markandeya Purana) from the British Museum collection. ${ }^{19}$ She proposes an identification of each register of the scrolls along with an overall summary of the Purana as summarized by Thurston and Rangachari in their 1909 Castes and Tribes of Southern India. ${ }^{20}$ The following summary of the Padmasali Purana synthesizes these two together along with Sadanandam's summary of the Bhavana Rishi story, and my personal assessment from different versions collected over the course of fieldwork in 2014 and 2015. ${ }^{21}$

The genealogy goes as follows: The sage Bhrigu was born to Brahma. Mrukanda was born to Bhrigu. Because Mrukanda was not given a son, he prayed to Shiva, who gave Mrukanda a choice: he could have a pious son who would die at sixteen, or an evil one who would live longer. Mrukanda chose the former and got a child named Markandeya. When Markandeya turned sixteen, Yamadharma Raja, the god of death, came to take him away. Mrukanda prayed to Shiva to save his son, and after Shiva battled with Yamadharma Raja, Markandeya was saved. In exchange for saving his life, Shiva ordered Markandeya to perform a sacrifice, and from the sacrificial fire, Bhavana Rishi, the weaver of the gods, appeared. Bhavana Rishi would make clothes for the gods with thread obtained from the lotus situated at Vishnu's navel.

An alternative version of the story supported by both J. Mittal and Thurston and Rangachari states that Markandeya himself was asked to weave for the gods and that he did tapas (penance) to achieve this, from which Bhavana Rishi appeared. The major difference here is that the connection to weaving comes from Bhavana Rishi in the first version and directly from Markandeya in the second, and the hesitation lies in whether the sacrifice was performed directly because Markandeya's life was saved or

19 Anna L. Dallapiccola, South Indian Paintings: A Catalogue of the British Museum Collection (London: British Museum Press, 2010).

20 Edgar Thurston and K. Rangachari, Castes and Tribes of Southern India (Madras: Government Press, 1909).

21 Sadanandam, Art and Culture, 92. 
because he was asked to weave in exchange for his life. The second version seems to go one step further in justifying the existence of Markandeya and its connection to the weaving activity, mediated through the appearance of Bhavana Rishi. Upon his appearance in the story, Bhavana Rishi made clothes for the gods and offered those clothes to them. He offered clothes to Bhairava, the "angry" manifestation of Shiva, who deemed the clothes unsuitable and refused to accept them. As a consequence, Bhairava uttered a curse that the clothes would wear out in six months. In response to Bhairava's curse, Shiva ordered Bhavana Rishi to provide him with a tiger's skin to wear. At this stage, another sage named Narada came to help Bhavana and told him to go to Udaigiri, where Bhadravati, Surya's daughter, was doing penance to secure Bhavana as her husband. She promised to give him a tiger's skin if he married her. Bhavana therefore went to the forest, where Bhadravati resided. Bhadravati provided Bhavana with a tiger. Bhavana used the tiger as his vehicle and proceeded to meet Shiva. On the way, he met a Raksha called Kaluva, who had come from the city Vishalaksha and had stolen Bhavana's loom to make clothes from jute for the Rakshas. Bhavana was unsuccessful in killing Kaluva and called for the help of an army of tigers, called Pulisainyam. With their help, he was able to kill Kaluva. An alternative version says that from the sweat that Bhavana was producing while fighting the Raksha, three people emerged, Adigadu, Padigadu, and Baladu, the founder of the Kunapuli community. The Kunapuli came in support of Bhavana, and Bhavana was finally able to kill Kaluva with their help. To thank them for their help, Bhavana told the Kunapuli that they would earn their livelihood by performing the Bhavana Rishi before the weavers/Padmasalis. Bhavana finally reached Shiva and offered him the tiger's skin. He then went back to Bhadravati, married her, and had a hundred and one sons. There are said to be one hundred ancestors of the Padmasalis, and the remaining one son is the ancestor of the silk weavers.

Each scroll starts with the same section, consisting of six registers in scroll $\mathrm{A}$, eight in $\mathrm{B}$ and $\mathrm{C}$, and nine in $\mathrm{D}$. These registers introduce the narrative, the worship of Ganesha and Vishnu, and the appearance of Bhavana Rishi, from Markandeya and himself from Mrukanda (scroll C; see fig. 1). This section, which is usually more than one-third of the scrolls, places Bhavana Rishi within the more classical narrative of the Markandeya 
Purana. Once Bhavana's existence is presented, the scroll starts describing his story and relationship with the gods, portraying how he came to be the founding figure of the Padmasalis. Finally, the last three to four registers, which start at the description of the goddess Gangamma, speak directly about the ancestors of the Padmasalis, sons of Bhavana, and how they present themselves in front of the local king, asking for a resolution of their status. In a general fashion, the scrolls of the Padmasalis are therefore divided into three sections: the Markandeya Purana, the Bhavana Rishi story, and the Padmasalis.

\section{Continuity}

When observing the available scrolls of the same narratives but from different dates or different regions, the first impression is a strong sense of continuity, perhaps even conservatism. While some narratives may be found depicted either horizontally or vertically, the Padmasali Purana is always depicted in vertical format and the scenes vary only a little. The variation in length is rather minor, and between the oldest scroll from 1625 (scroll A), which measures 845 centimeters, and the latest from 2000 (scroll E), which measures 915 centimeters, there is less than a meter difference. The width varies only a little, too, and does not increase over time but rather fluctuates between 85 and 91 centimeters. An increase in length and registers over time does not necessarily mean an increase in the number of scenes but, instead, a grander subdivision of the narrative space. Each of the narrative's episodes is represented regardless of the scroll's length and amount of registers.

The overall arrangement of the painting surface is the same for all of the scrolls. The narrative is divided into registers, which are themselves divided into scenes. Several continuous narratives may be depicted in one register without any border to separate them. All the scrolls of the Padmasali Purana start with a painting of Ganesha, sitting in lalitasana, or half-meditation pose, on a throne, with a bandicoot at his feet, and flanked by one devotee on each side (scroll C; see fig. 1). With the exception of scrolls B and E, all are followed by an image of Vishnu reclining on a leaf with his two female 
consorts Sri Devi (also known as Laxmi) and Bhu Devi at his feet. From his navel, a lotus flower emerges with Brahma inside. Seven rishis are depicted on the leaves sprouting from Vishnu's banyan leaf: Kashyapa, Atri, Vasishtha, Vishvamitra, Gautama, Jamadagni, and Bharadvaja. ${ }^{22}$ Underneath Vishnu's leaf, all scrolls have a white waterscape with fishes, elephant, and Kurma, the tortoise avatar of Vishnu. The scene probably represents the Samudra Manthan episode, the Churning of the Ocean of Milk and the creation myth in Hinduism.

The frontal image of Ganesha and the scene with Vishnu and the creation myth are rather fixed and reproduced at the beginning of each scroll of the Padmasali. This section of the scroll will not be used within the narrative directly by the storytelling performance but rather will serve as an introductory phase to it, a moment of worship for the audience and the performers before the beginning of the narrative. Because of their religious importance, these two registers take up a fair amount of space in the overall scroll. Similarly, every event of importance in the narrative will take a larger register to be depicted. For instance, the tale of Bhavana Rishi riding the tigers and fighting the demons is found in all the scrolls.

Among other features common to all the scrolls are the use of bright red for the background and the use of contrasting blues and ochres/yellows for the figures. Apart from variations in pigment quality and technique depending on the painter, all the scrolls use the conventional formula of a red background with contrasting colored figures, including the most recent scroll (E). In complement, the borders are white or yellow, decorated with floral motifs and contrasting with the red background. As a general rule, the figures do not exceed the registers in which they have been assigned, with the exception of a few crowns.

Scrolls C and D show strong similarities in the organization of the pictorial surface, the style, and the iconography. These two scrolls develop the narrative on respectively twenty-six and twenty-seven registers, devoting eight and nine registers to the first section, that of the worship of Ganesha, the myth of creation, and the Markandeya Purana. It stops when Bhavana

22 Dallapiccola, South Indian Paintings, 228. 
Rishi enters the story respectively in the ninth register for scroll C (see fig. 1) and in the tenth for scroll D. In both these scrolls, the marriage of Bhadravati and Bhavana, in the twenty-first register for scroll $\mathrm{C}$ (see fig. 1) and in the twenty-third for scroll $\mathrm{D}$, is depicted in a similar manner, with an elephant on the left and a horse on the right. Similarly, the two scrolls have a blue band register itself bordered at the top and bottom by a yellow floral border as the first register.

The two scenes when Bhavana enters the forest are also interesting in this regard. The first scene is when Bhavana enters the forest and sees animals, trees, fruit gatherers, and so on, and an elaborate depiction of the Gandaberunda, a two-headed magical bird widely used in South Indian Hindu iconography (scroll C, reg. 16 [see fig. 1]; scroll D, reg. 18). The second scene is the meeting with Bhadravati standing with her hands folded in namaskar and flanked by her servants (scroll C, reg. 17; scroll D, reg. 19). In both scrolls, the figures and elements of the composition may vary in color but are disposed in exactly the same manner. The number of characters, trees, and animal figures is exactly the same. The placement of mirrors and other small objects or even gestures is also identical.

These observed similarities contrast with scroll B, which shares stylistic features with scrolls C and D but has differences as well. Scroll B develops the narrative into twenty-four registers, with eight for the Markandeya Purana section, which is equal to that section's length in scrolls C and D. The marriage procession is depicted in a similar style, but in scroll B (reg. 20), the elephant is on the left and the horse on the right. In the scenes with the Gandaberunda and the meeting with Bhadravati, the organization is again different. The Gandaberunda (scroll B, reg. 15) is at the center, but in scroll $\mathrm{B}$, Bhavana enters the registers from the right, whereas he enters from the left in scrolls C and D. In scroll B there is a larger number of figures in that scene, too, which is busy with forest activities such as picking fruits, hunting, and so on. A group of animals is depicted on the left, which is not shown in scrolls $\mathrm{C}$ and $\mathrm{D}$. As for the scene where Bhavana meets Bhadravati, the disposition is reversed here, too (scroll $\mathrm{B}$, reg. 16); Bhavana enters from the left instead of the right and meets with the fierce animal, while Shiva and Parvati, riding above, are on the right instead of the left. Finally, in scrolls $\mathrm{C}$ and $\mathrm{D}$, these two scenes of Bhavana in the forest are directly 
followed by the main scene in which Bhavana rides the tiger and fights the demon's army (scroll C, reg. 18; scroll D, reg. 20), whereas scroll B integrates another scene before this one that is difficult to identify: women seem to be talking to demons while a bunch of men dressed in the courtly attire of the Deccan fashion are playing instruments and seem to be involved in celebrations (scroll B, reg. 17).

The particularities expressed above highlight two important facts about the scroll-painting tradition. The first is the noticeable inflexibility of the scroll-painting tradition, and the necessity of such constancy. All share a similar narrative in a similar order - that is, the Markandeya Purana, the Bhavana Rishi, and the Padmasali Purana. Even when scenes are inserted, like the one with men playing instruments, it does not mean that another is deleted. There is very little chance that a major narrative scene will not be found in a scroll at all. The Deccani musician scene does not alter the overall narrative of filiation in any way but instead serves a historicization purpose that places the scroll within its own time without changing the narrative. At times, a register may include scenes that will be seen in three different registers in another scroll, yet all the scenes are depicted in all the scrolls. This is easy to compare with scrolls $\mathrm{B}, \mathrm{C}$, and $\mathrm{D}$, which all come from around the same period between the mid-eighteenth and early nineteenth centuries. The earlier scroll A has greater differences, although the major scenes of the Puranas are found there too. Similarly, the latest scroll (E) gathers all the scenes relevant to the filiation narrative as well.

\section{Incremental Changes}

A closer look at the scrolls together provides nuance for this consistency in the scroll depiction. Each scroll displays a small degree of variation in the order or the number of registers or the disposition of figures. These changes do not occur drastically from one scroll to the next copy but instead, over time, through slow and incremental additions. For instance, it seems that over time, the narratives tend to expand rather than reduce. Having one much older scroll (A, ca. 1625) and one much more recent (E, ca. 2000) here is very useful to jump historically into the painting style. Scroll A 
depicts the narrative in twenty-two registers. In between, scroll (B) contains twenty-five registers, and scrolls $\mathrm{C}$ and $\mathrm{D}$ each contain twenty-seven registers. The latest scroll from 2000, scroll E, contains twenty registers. Most of the scenes are the same for all the scrolls, but the most recent scrolls tend to subdivide scenes rather than joining several scenes into one register, which is partly the reason for the elongation of the scroll. This observation on the number of registers reinforces the possible dating that I presented earlier.

Another observation may be made about the costumes. In the oldest scroll (A), the men's costumes were a bare chest and a patterned dhoti, leaving the Deccani jama coat to be worn solely by the king in the final register. When the later scrolls were made, the Deccani fashion of the jama coat had become more popular and thus could be seen on the noblemen as well as the king in the illustrations. As I explained earlier, these changes do not alter the narrative in any way and do not hamper the performers' necessities. Perhaps, too, these may be welcome as a contemporization of their performance through an adaptation of its visual form to the most recent fashion.

Other changes occur in elements of decoration and ornaments, as well as in the borders and naturalism of the figures. These are stylistic features that do not change the fixity of the narrative's iconography and that may evolve over time. For instance, the borders that separate registers in scroll $\mathrm{A}$ are homogeneous throughout, all blue with white flowers. In the later scrolls of the eighteenth and nineteenth centuries (B, C, D, and E), each border seems to have a different color combination and pattern, which makes these scrolls visually noisier than the early scroll. Similarly, the earlier scroll offers a well-balanced pictorial surface where the architectural elements are straight and contrast with the flowing roundness of the figures, proportionately disposed on the surface and usually regular in size. The latest scroll, scroll E, offers a completely different feeling, with greater variations in figure size, color, architectural elements, and so on.

These variations in the painting style do not impair the narrative in any way. Overall, the necessities of the narrative impose an important degree of fixity in the painting, which is manifested in the iconography, whereas changes in style and decorative motifs seemed to be accepted and embraced 
Manuscript Studies, Vol. 4 [2019], Iss. 1, Art. 6

Da Fonseca, Folk Narratives of Telangana

over time or over regions so long as they did not alter the iconography and served the purpose of these genealogies in rendering them more truthful.

\section{The Most Recent Scroll}

To complete this observation of the scrolls, it is important to look at the most recent scroll, from circa 2000, scroll E. Unfortunately, we do not have scrolls of the Padmasali Purana collected between the mid-nineteenth century and the early twenty-first century, which means there are nearly a hundred years for which we cannot observe stylistic change. Nevertheless, we can observe a simplification in style over time. While it seems that decorative elements increased between the seventeenth and the early nineteenth centuries, decoration decreased from the nineteenth century to the twentyfirst. The most striking element to observe in this regard is the costumes, which are an important part of the Padmasalis' identity as weavers and therefore a particularly important motif in the scrolls. Unlike other scrolls, the scrolls of the Padmasali tend to depict a grander variety of costumes and pattern designs on their clothes. The oldest scroll (A) has deep shades of indigo with beautifully drawn flower motifs in contrasting white. The later scrolls (B, C, and D) increased the variety, and like the borders, the textile patterns seem to vary widely within the same scroll. Jewelry, too, is depicted as subtle and flowing in the oldest scroll (A) and is less fine but more varied in the eighteenth- and nineteenth-century scrolls (B, C, and D).

A surprising change in scroll $\mathrm{E}$ is the almost complete disappearance of textile motifs. Both gods and other figures wear simple dhoti and bare chests. Only Vishnu gets a slight pattern on his dhoti, and a few female figures get a slight change in the depiction of saris, which have a longer blouse, possibly reflecting contemporary fashion. Ornaments and jewelry are minimal and depicted on females and gods only. The Deccani court fashion found throughout the eighteenth- and nineteenth-century scrolls is absent.

In contrast, scroll $\mathrm{E}$ has a greater representation of fields and farming scenes with an attempt at perspective that was not seen before (see fig. 2). This may be explained by the increasing exposure of painters to Western 
modes of depiction through formal art school training. In addition, with the recent shift in patronage that took place in the painting tradition, painters have developed new secular iconography that translates mostly into what the painters call "village" scenes. These scenes represent rural activities in the bold "authentic" and "rural" style, as per the demands of the handicrafts market. It is possible to see the inclusion of such scenes in the sacred narrative of the Padmasalis as a consequence of these new developments in patronage. If we think of the eighteenth- and nineteenth-century scrolls depicting Hindu kings wearing the typical costumes then worn at the Deccani Muslim courts as a marker of their contemporaneity, we may expect to see indications of alternative patronage in the most recent scroll as well. Perhaps the painters of scroll E drew some of their iconographic motifs from paintings produced for other patrons, or by encountering these in different visual forms.

Regardless, the farming scene and the Deccani costumes do not directly take part in the overall narrative, nor do they alter the sacred genealogies of the Padmasali; they only reflect the painters' liberties toward scroll making and indicate elements of contemporaneity. It is not without importance that these elements are the most difficult to identify in scroll E, and the musician scene of the nineteenth-century scrolls is almost impossible to identify as it does not take part in the narrative; nor does the farming scene. These scenes are illustrative of underlying influences, reflecting the painters' or performers' own time.

\section{Replication}

There is one particular way to understand the concept of replication in the context of the scroll-painting tradition from Telangana. As one looks at the scrolls over time, there are numerous constant features, but there are numerous changes in style and materiality, too. The changes that occur over time mostly relate to the overall look of the scroll, its visual features, whereas the narratives tend to remain the same. With the exception of a few figures that vary and alteration in the placement of scenes, the episodes of the narrative 
are rather constant. In terms of materiality, the quality of pigments changes over time, as does the quality of the canvas. Style, however, depends on the artist. Depending on who is drawing the black line, there may be a different fluidity in the figures. The composition over time has tended to become more crowded due to the addition of ornaments and architectural elements, and a reduction in size of each register. But these elements do not alter the narrative and the episodes of the narrative.

It is not the painting style that is fixed and conservative but rather the function of the narratives depicted in the paintings. The genealogies serve a legitimization purpose, and this legitimization is conveyed through a performance that uses the scrolls as its background for two reasons: to help the storytellers in their performance and to assert the authenticity of the narrative they perform. This consequential structure demands a certain visual fixity to serve both these functions. As long as the narrative is not altered, stylistic changes are not a concern, and the painting remains a reproduction of another.

A comparison may be drawn here with the Rajasthani phad, a scroll painting used for performances of cattle hero stories such as that of Devrayanan and Pabuji. As Kavita Singh explains in her article on the subject, in a phad painting, "a 90-year-old villain and a 12-year-old hero are represented by the same figural type." ${ }^{23}$ This way, she explains, the figures could then be used at the performer's convenience depending on his oral narrative. Like the scrolls in Telangana, the Rajasthani phad show purposeful inflexibility over time, similarly justified in the unquestionable relationship between painter and performer and in the function of the scroll, which is to support rather than illustrate a highly adaptable oral narrative. ${ }^{24}$ This type of narrative demands an inflexible generalization to conform to the performer's oral skills, that of memory and improvisation at the same time. In that sense, in Rajasthan like in Telangana, when new

23 Kavita Singh, "Transfixed by the Arrow of Time: Phad Paintings of Rajasthan," in Indian Painting: The Lesser-Known Traditions, ed. Anna L. Dallapiccola (New Delhi: Niyogi Books, 2011), 116.

24 Singh, "Transfixed by the Arrow of Time," 116-18. 
scrolls are commissioned, the performers visit their respective painters with an old scroll and commission a "copy." In the making of a Rajasthani phad, Singh explains that this process is identified as chbapna (printing). ${ }^{25}$ In both cases, the narrative is not entirely known by the painters; it is only reproduced, either "copied" or "printed" from one support to the other.

As discussed earlier, when a new scroll is being commissioned, whether it is because the previous one is too old or because a new family is starting the activity, the performers visit the painters' house with the old scroll and request a new copy. The old scroll will serve as a model to sketch the narrative onto the new canvas. Many times, painters do not know the performers' stories, at least not in detail; nor do they wish or need to. Because they "copy" from the previous one, it is neither usual nor necessary for painters to collect and know the stories. Vaikuntam, who is now the eldest painter of this tradition, accumulates a few sketches of the figures that he should remember or that may be peculiar to one particular scroll in a small-sized sketchbook and remembers major elements of each narrative that he has painted on several occasions. But this does not by any means equate to the performers' knowledge of the story. It is essential to understand the painter's impact on the material and pictorial features of the scroll. Both painters and performers believe one scroll is a copy of the previous. Again, this is mostly due to the fact that the narrative does not and should not be changed in order to keep its authenticating function but also to be practical for the performers.

In conclusion, the concept of replication is intimately linked to the idea of fixity in the scroll for the performance-painting tradition in Telangana. The fixity of the painting practice reflects its function, that of legitimizing a community's existence. In art historical terms, this fixity also allows us to have an idea of what scrolls were in the past, in most part similar to what they are now. This does not mean that elements of variation are absent; such variations mostly reflect a scroll's contemporaneity instead of grounding it in its legitimizing past. To bring this back to the communities that interact with the scrolls in this process, while the fixity mostly belongs to

25 Singh, "Transfixed by the Arrow of Time," 117. 
Manuscript Studies, Vol. 4 [2019], Iss. 1, Art. 6

the patrons, variation mostly belongs to the painters. Performers stand in between, mediating fixity and contemporaneity toward the same goal, the telling of a fixed and elevating genealogical narrative in an entertaining performance grounded in time and space. In this context, the concept of replication speaks not only for the painting tradition but also for contributing to our understanding of these three communities and their interactions. 